\title{
Evaluation of Potassium Quantity-Intensity in some Soils of El-Dakhla Oasis, New Valley, Egypt \\ Mahdy H. Hamed ${ }^{1}$, Abu El-Eyuoon Abu Zied Amin ${ }^{2}$
}

\begin{abstract}
The current research was carried out in 2016 to evaluate potassium Quantity-Intensity parameters and the relation of these parameters to the characteristics of some agricultural soils of El-Dakhla Oasis, New Valley, Egypt. Six surface soil samples $(0-30 \mathrm{~cm})$ were collected from different sites in El-Dakhla Oasis. The values of equilibrium activity ratio of potassium $\left(A R^{k}{ }_{0}\right)$ ranged between 0.0071 (soil 3) to $0.0320(\mathrm{~mol} / \mathrm{L})^{1 / 2}($ sample no. 1$)$. The labile $K\left(-\Delta K^{0}\right)$ values also, varied from 0.020 (sample no. 4) to $0.412(\mathrm{cmol} / \mathrm{kg}$ soil (sample no.1). The values of the potassium potential buffering capacity $\left(\mathrm{PBC}^{\mathrm{K}}\right)$ of soil ranged from 0.964 to $12.86\left[\left(\mathrm{Cmol} \mathrm{kg}^{-1} /\left(\mathrm{mol} \mathrm{L}^{-1}\right)^{0.5}\right]\right.$. Generally, the highest value of $\mathrm{AR}^{\mathrm{k}}{ }_{0}, \Delta \mathbf{K}^{0}, \quad \mathbf{P B C}^{\mathrm{K}}$ parameters were related in soil sample no. $1[(0.032$ $(\mathrm{mol} / \mathrm{l})^{0.5}, 0.412 \mathrm{cmol} / \mathrm{kg}$, and $12.86\left[\left(\mathrm{cmol} \mathrm{kg}^{-1} /\left(\mathrm{mol} \mathrm{L}^{-1}\right)^{0.5}\right]\right.$, respectively. The $A R^{k}$ was a negatively significant correlated with exchangeable potassium $(\mathrm{r}=-0.822)$, Organic matter (-0.633) and available $K$ (-0.444). A positive highly significant correlation was obtained between the labile $K\left(-\Delta K^{0}\right)$ and both exchangeable $C a$ and $\mathrm{Mg}\left(\mathrm{r}=\mathbf{0 . 9 3 6}\right.$ and 0.941 , respectively). The $\mathrm{PBC}^{\mathrm{K}}$ showed a positive significant correlation with clay content, available $\mathrm{K}$ and cation exchangeable capacity (CEC), and negative significant correlations with soil $\mathrm{pH}(\mathrm{r}=-\mathbf{0 . 7 9 5})$ and $\mathrm{CaCO}_{3}$ $(\mathrm{r}=\mathbf{- 0 . 6 3 3})$.
\end{abstract}

Key words: Quantity/Intensity parameters, Potassium kinetics, El-Dakhla Oasis.

\section{INTRODUCTION}

Potassium (K) is considered an essential macronutrient which is required relatively large amounts for plant growth. The soil potassium content can be classified into three categories; (1) the readily available form (soluble and exchangeable potassium), (2) the slowly available one (the non-exchangeable potassium), and (3) the unavailable form that includes the potassium in the structure of silicate minerals such as feldspars and micas (Brady, 1984). The availability of $\mathrm{K}$ in the soil solution, and the capacity of soil to buffer this concentration are among the important parameters that determine the effective available $\mathrm{K}$ for plants (Raheb and Heidari, 2012). The forms and dynamics of soil potassium are affected by changes in vegetative cover and biomass production (Awdenegest et al., 2013). The

\footnotetext{
${ }^{1}$ Department of Soils \& Water, Faculty of Agriculture, Assiut University, New Valley, Egypt

${ }^{2}$ Department of Soils \& Water, Faculty of Agriculture, Assiut

University,Egypt

Email: Mahdy82@yahoo.com

Received March 9, 2017, Accepted March 30, 2017
}

quantity/intensity $(\mathrm{Q} / \mathrm{I})$ ratio of potassium has been vastly disseminte in the scientific works to assess the $\mathrm{K}$ status in the soils. In this approach, immediate available $\mathrm{K}$ is related to the intensity factor, the reserve of the non-exchangeable $\mathrm{K}$ is referred to the quantity factor and the renewal capacity is applied to the buffering capacity (Royet al., 1991; Hamdan et al., 1999; Wang et al., 2004). The same time different soil having same equilibrium activity ratio of potassium $\left(\mathrm{AR}_{\mathrm{e}}{ }^{\mathrm{k}}\right)$ values may not possess the capacity for keeping $\mathrm{AR}_{\mathrm{e}}{ }^{\mathrm{k}}$ when soil $\mathrm{K}$ is decreased (Diattaet al., 2006). The potassium potential buffering capacity $\left(\mathrm{PBC}^{\mathrm{K}}\right)$ describe soil capacity to resist changes in the content of available potassium under the impact of natural and anthropogenic factors (Zharikova, 2004). Several endeavors have been made to describe the relationship between the intensity of $\mathrm{K}$ and the buffering capacity of soil K content. Evangelou et al. (1994) reported that the high value of labile $\mathrm{K}$ indicates an increased release of $\mathrm{K}$ in the soil solution as a result of a greater pool of soil potassium. The high value of the potential buffering capacity of potassium $\left(\mathrm{PBC}^{\mathrm{k}}\right)$ implies that the availability of $\mathrm{K}$ is good, while the low value of $\mathrm{PBC}^{\mathrm{k}}$ indicates that $\mathrm{K}$ fertilization is required. This study aims to evaluate the quantity/intensity parameters of soil potassium and their relationship between these parameters and some soil properties in El-Dakhla Oasis.

\section{MATERIALS AND METHODS}

Locations: Soil samples were collected from different sites represented the agricultural soils of Dakhla Oasis, that is located in the middle of the Western Desert of Egypt between latitudes $25^{\circ} 29^{\square}$ to $25^{\circ} 55^{\square} \mathrm{N}$ and longitudes $28^{\circ} 30^{\square}$ to $29^{\circ} 32^{\square}$ E (Fig 1). The soil samples were air-dried, crushed, passed through a $2 \mathrm{~mm}$ sieve and kept for analysis. The soil particle-size distribution was determined by the pipette method according to Jackson, (1969). The saturation percentage was measured as described by Hesse (1998). Organic matter was determined by the Walkley-Black method outlined in Jackson, (1973). Soil pH was determined in $1: 2.5$ of a soil deionized water suspension by Jackson, (1973). Total calcium carbonate was estimated using a manometric calcimeter (Nelson, 1982). 


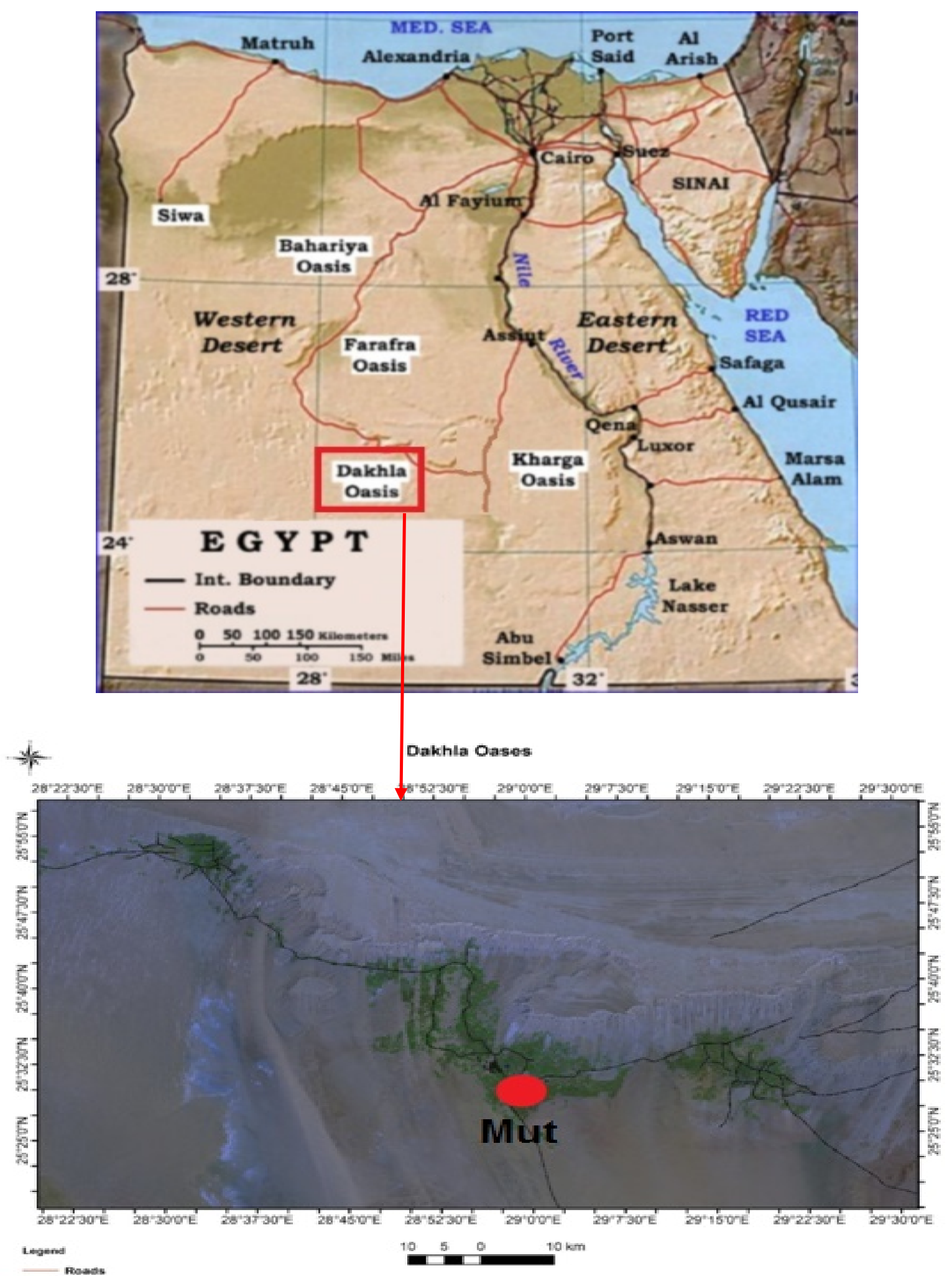

Figure 1. General map of Egypt and location of El-Dakhla Oasis map 
The electrical conductivity (EC) was determined in a 1:2.5 of a soil to water extract using an electrical conductivity meter (Hesse, 1998). The cation exchange capacity (CEC) and the exchangeable cations $(\mathrm{Ca}, \mathrm{Mg}$ and $\mathrm{K}$ ) of the soil sample were determined according to Baruah and Barthakur, (1997). Available P was determined by $0.5 \mathrm{M} \mathrm{NaHCO}_{3}$ extract at $\mathrm{pH}$ of 8.5 as described by Olsen et al.(1954).

\section{Quantity/Intensity of potassium:}

The quantity/intensity of potassium was detrimined by adding $50 \mathrm{ml}$ of $10 \mathrm{mM} \mathrm{CaCl}$ solutions containing various concentrations of potassium $(0,0.2,0.4,1,2$ and $4 \mathrm{mmol} / \mathrm{l}$ from $\mathrm{KCl}$ ) to $5.0 \mathrm{~g}$ of the soil sample in bottles. The soil suspensions in the bottles were shaken for 2 hours, then left for overnight ( 24 hours) to complete equilibrium and centrifuged at $4000 \mathrm{rpm}$ from $5 \mathrm{~min}$. The suspension of soil samples was filtered and the supernatants were construe for potassium using flame photometer (PFP7), calcium, and magnesium. Potassium in equilibrium solutions was measured using the flame photometer while calcium plus magnesium was determined by the titration using ethyline-diamine tetra acetic acid (EDTA) solution. The factor of $\mathrm{K}$ quantity $(\Delta \mathrm{K})$ was computed from the difference in $K$ concentration between the initial and equilibrium solutions. The activity coefficient of an ionic species was measured by using the Davies equation given by (Sposito, 1989) as:

$$
\log \gamma=-0.512 Z^{2}\left[\left(I^{0.5} / 1+I^{0.5}\right)-0.3 I\right]
$$

Where $\mathrm{Z}=$ the charge of $i$ ionic species and $I=$ the ionic strength that was calculated as follows:

$$
I=1 / 2 \Sigma \mathrm{C}_{\mathrm{i}} \mathrm{Z}_{\mathrm{i}}^{2}
$$

Where $\mathrm{C}_{\mathrm{i}}$ is the concentration of $i$ species in mmol/L

A plot of $\Delta \mathrm{K}$ on the ordinate axis and activity ratios of $\mathrm{K}\left(\mathrm{AR}^{\mathrm{K}}\right)$ on the abscissa axis was constructed for each treatment to obtain the $\mathrm{Q} / \mathrm{I}$ curve. Equilibrium activity ratios of $\mathrm{K}\left(\mathrm{AR}_{0}^{\mathrm{K}}\right)$ were extrapolated from $\mathrm{x}$ intercepts of the $\mathrm{Q} / \mathrm{I}$ plots at zero level of $\Delta \mathrm{K}$. The value of $-\Delta \mathrm{K}^{0}$ (labile $\mathrm{K}$ ) was extrapolated from $\mathrm{y}$-intercept of the $\mathrm{Q} / \mathrm{I}$ plots. The potential buffering capacity for $\mathrm{K}$ $\left(\mathrm{PBC}^{\mathrm{K}}\right)$ is the slope of the $\mathrm{Q} / \mathrm{I}$ curve (Usman and Gameh, 2008).

\section{RESULTS AND DISCUSSION}

\section{Soil properties:}

The soil physico-chemical properties are shown in Table 1. The results indicate that the soil samples have different soil texture. The clay content in soil 1 is relatively high, suggesting its ability to retain $\mathrm{K}$. On the other hand, the soil 4 and 5 contained a relatively high sand fraction. The soil organic matter $(\mathrm{OM})$ varied from
$0.60 \mathrm{~g} / \mathrm{kg}$ (soil 4) to $15.5 \mathrm{~g} / \mathrm{kg}$ (soil 1). The high value of $\mathrm{OM}$ in soil 1 and 3 may be due to the high of clay and loam contents in these soils. Soil $\mathrm{pH}$ ranged from 7.58 (soil 1) to 8.85 (soil 4). So, most of the soils studied were slightly alkaline except soil 4 that is considered strongly alkaline. The soil salinity ranged from 2.02 $\mathrm{dS} / \mathrm{m}$ (soil 5) to $9.17 \mathrm{dS} / \mathrm{m}$ (soil 4). The high level of EC may be due to the high content of chlorides of sodium, magnesium, and calcium sulfate. The cation exchange capacity (CEC) varied between 9.63 to $39.7 \mathrm{cmol} \mathrm{kg}^{-1}$. The exchangeable potassium $\left(\mathrm{K}_{\mathrm{ex}}\right)$ ranged from 0.08 to $0.46 \mathrm{cmol} \mathrm{kg}^{-1}$; exchangeable $\mathrm{Ca}$ varied from 1.74 to $29.31 \mathrm{cmol} \mathrm{kg}^{-1}$ soil, exchangeable $\mathrm{Mg}$ differed from 1.06 to $17.61 \mathrm{cmol} \mathrm{kg}^{-1}$ soil. The $\mathrm{K}$ saturation is considered a value that expresses mobility parameters. $\mathrm{K}$ saturation was low in all soil samples except soils 2 and 6 which showed a relatively high potassium concentration (Yawson et al., 2011). Also, the content of $\mathrm{CaCO}_{3}$ ranged from 28.70 to $268.40 \mathrm{~g} / \mathrm{kg}$ andSoil available K ranged from 46.2 to $139.3 \mathrm{mg} / \mathrm{kg}$. The high content of available Kin some soils may be attributed to the high content of clay and organic matter in these soils.

\section{Quantity-Intensity (Q/I) Parameters \\ Equilibrium activity ratio of potassium $\left(\mathrm{AR}^{\mathrm{k}}{ }_{0}\right)$ :}

The Equilibrium activity ratio of $\mathrm{K}\left(\mathrm{AR}_{\mathrm{o}}^{\mathrm{k}}\right)$ is obtained to measure the intensity of a labile $\mathrm{K}$ in the soil (Intensity factor) and represents the $\mathrm{K}$ that is instantly available to crop roots (Yawson et al., 2011). The values of $\mathrm{AR}^{\mathrm{k}}{ }_{\mathrm{o}}$ ranged between 0.0071 and $0.0320(\mathrm{~mol} / \mathrm{L})^{0.5}$ (Table 2 and Figure 2). The soil 1 showed a higher $\mathrm{AR}^{\mathrm{k}}{ }_{\mathrm{o}}$ value compared to the rest of soils. On the other hand, a lower $\left(\mathrm{AR}^{\mathrm{k}}{ }_{\mathrm{o}}\right)$ value was recorded for the soil 3. The higher values of $\mathrm{AR}^{\mathrm{k}}{ }_{\mathrm{o}}$ may be due to smaller exchangeable $\mathrm{K}$ percentage (EKP) as well as to potassium fertilization (Schneider, 1997). Sparks and Liebhardt, (1981) suggested that the adsorbed K was held at planer positions wherever the $\mathrm{AR}^{\mathrm{k}}$ ovalues were $>0.01(\mathrm{~mol} / \mathrm{L})^{0.5}$. Also, the low values of exchangeable $\mathrm{Ca}$ and $\mathrm{Mg}$ which increase the $\mathrm{AR}^{\mathrm{k}}{ }_{\mathrm{o}}$ values (Lalitha and Dhakshinamoorthy, 2015). In the current study, the $\mathrm{AR}_{0}^{\mathrm{k}}$ values were higher than those reported by Wang et al.(2004), they found that the soils that have low values of $\mathrm{K}_{\mathrm{ex}}$, and their $\mathrm{AR}_{\mathrm{o}}^{\mathrm{k}}$ ranged from 0.001 to 0.010 $(\mathrm{mol} / \mathrm{l})^{0.5}$.

\section{The labile $K\left(-\Delta K^{0}\right)$ :}

The labile $K\left(-\Delta K^{0}\right)$ represents the available amount of $\mathrm{K}$ capable of ion exchange during the equilibrium between soil solids and solution (Lalitha and Dhakshinamoorthy, 2015). It has to maintain a balance between $\mathrm{K}$ on the soil colloids and $\mathrm{K}$ in soil solution by ionic exchange. 


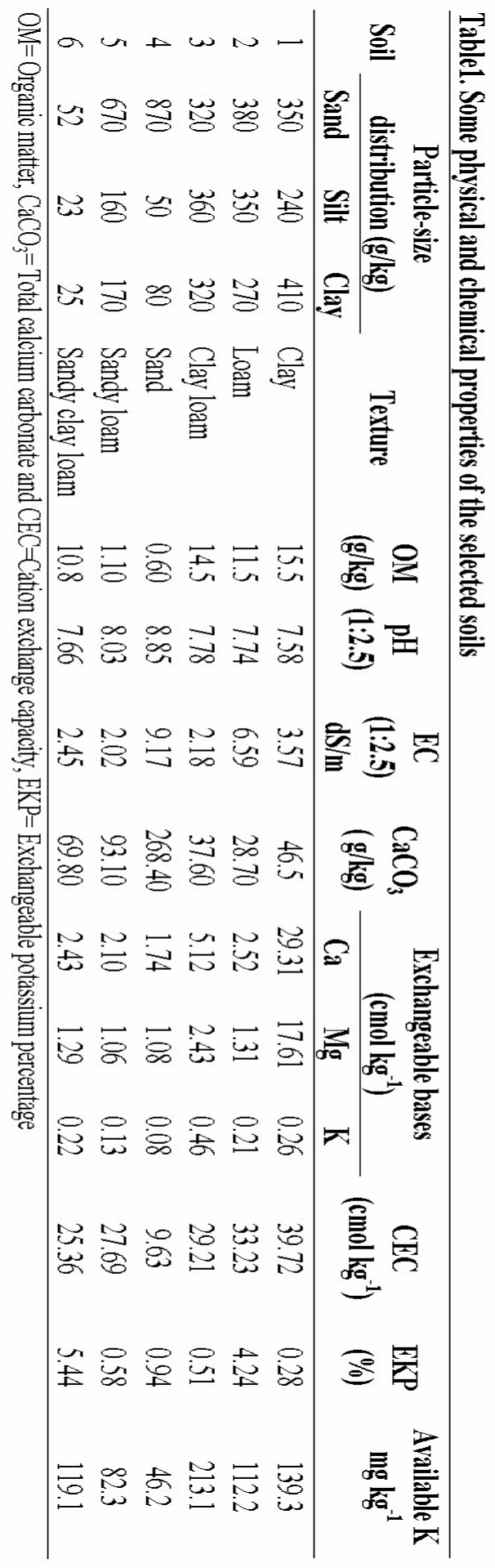


Table 2. The quantity-intensity $(\mathrm{Q} / \mathrm{I})$ parameters of the experimental soils

\begin{tabular}{clcccc}
$\begin{array}{c}\text { Soil } \\
\text { No. }\end{array}$ & Linear equation & $\mathbf{R}^{\mathbf{2}}$ & $\begin{array}{c}\mathbf{A R}_{\mathbf{0}}^{\mathbf{k}} \\
(\mathbf{m o l} / \mathbf{l})^{\mathbf{0 . 5}}\end{array}$ & $\begin{array}{c}-\Delta \mathbf{K}^{\mathbf{0}} \\
\left(\mathbf{c m o l ~ k g}^{\mathbf{- 1}}\right)\end{array}$ & $\begin{array}{c}\mathbf{P B C}^{\mathbf{K}} \\
\left.\left[\mathbf{( c m o l ~ k g}^{-\mathbf{1}} / \mathbf{m o l ~ l}^{\mathbf{- 1}}\right)^{\mathbf{0 . 5}}\right]\end{array}$ \\
\hline 1 & $\mathrm{y}=12.86 \mathrm{x}-0.412$ & 0.994 & 0.0320 & 0.412 & 12.86 \\
2 & $\mathrm{y}=6.495 \mathrm{x}-0.125$ & 0.988 & 0.0192 & 0.125 & 6.495 \\
3 & $\mathrm{y}=4.493 \mathrm{x}-0.032$ & 0.978 & 0.0071 & 0.032 & 4.493 \\
4 & $\mathrm{y}=0.964 \mathrm{x}-0.02$ & 0.643 & 0.0207 & 0.020 & 0.964 \\
5 & $\mathrm{y}=3.286 \mathrm{x}-0.067$ & 0.982 & 0.0204 & 0.067 & 3.286 \\
6 & $\mathrm{y}=9.043 \mathrm{x}-0.127$ & 0.947 & 0.0140 & 0.127 & 9.043 \\
\hline
\end{tabular}

$\mathrm{x}=$ Activity ratio and $\mathrm{y}=$ Labile $\mathrm{K}$

The labile $\mathrm{K}$ values of the soil samples varied from 0.020 to $0.412 \mathrm{cmol} \mathrm{kg}^{-1}$ soil (Table 2 and Figure 2). The highest value of labile $\mathrm{K}$ was recorded in soil 1 $\left(0.412 \mathrm{cmol} \mathrm{kg}^{-1}\right)$. This high value of labile $\mathrm{K}$ may be attributed to the high CEC values and amount of loosely bound $\mathrm{K}^{+}$ions present in exchangeable site (Samadi, 2006). Also, the high values of labile $\mathrm{K}$ due to a greater $\mathrm{K}$ release into the soil solution, resulted in an increase in availability of $\mathrm{K}$. Also, $\mathrm{K}$ fertilizer may be increase the labile $\mathrm{K}$ in the soil (Yawson et al., 2011). On the other hand, the lowest labile $\mathrm{K}$ value of soil $4\left(0.020 \mathrm{cmol} \mathrm{kg}^{-}\right.$ ${ }^{1}$ ) was due to the more retention of $\mathrm{K}$ because of the presence of montmorillonite clay mineral (Lalitha and Dhakshinamoorthy, 2015). In generall, most of the potassium added through mineral fertilizer or released from organic amendments in the calcareous or sandy soils (soil 4) are susceptible to leaching due to their lower CEC or clay content compared to high clay content in soil 1 , that maintains a great amount of $\mathrm{K}$ on the clay exchange sites. On the other hand, the lowest labile $\mathrm{K}$ value of the studied soil sample $4(0.020 \mathrm{cmol}$ $\mathrm{kg}^{-1}$ ) may be related to the low clay content and CEC. Also, most of the potassium added through mineral fertilizer or released from organic amendments in the calcareous or sandy soils (soil 4) released to the soil solution due to their lower CEC and clay content compared to high clay content in soil 1 that maintains a great amount of $\mathrm{K}$ exchanged on its clay particles. Moreover, some clay minerals such as vermiculite can fix the labile $\mathrm{K}$ between their layers which could be considered non-exchangeable form (Fanning et al., 1989).

\section{Potential buffering capacity of potassium $\left(\mathrm{PBC}^{\mathrm{K}}\right)$ :}

The $\mathrm{PBC}^{\mathrm{K}}$ is the ability of a soil to maintain the intensity of $\mathrm{K}$ in soil solution. The $\mathrm{PBC}^{\mathrm{K}}$ values of selected soil samples varied from 0.964 to $12.86 \mathrm{cmol}$ $\mathrm{kg}^{-1}$. All soil samples except soil 4 had high values of $\mathrm{PBC}^{\mathrm{K}}$ (Table 2 and Figure 3 ). The $\mathrm{PBC}^{\mathrm{k}}$ values are divided into very low $\left(20 \mathrm{cmol} \mathrm{kg}^{-1}\left(\mathrm{molL}^{-1}\right)^{1 / 2}\right)$ and high $\left(>200 \mathrm{cmol} \mathrm{kg}^{-1}\left(\mathrm{molL}^{-1}\right)^{1 / 2}\right)$ (Zharikova, 2004). The variations in the $\mathrm{PBC}^{\mathrm{K}}$ values of the study soil samples could be attributed to the variations in the texture, parent material, addition of crop residues and mineralogy of the soils (Al-Zubaidi et al., 2008). The high soil PBC ${ }^{\mathrm{k}}$ value is an indication of good $\mathrm{K}$ availability, whereas a low PBCk soil would suggest a need for frequent $\mathrm{K}$ fertilizer application (LeRoux and Sumner, 1968). The high $\mathrm{PBC}^{\mathrm{K}}$ values of the soils indicate a greater capacity for maintaining $\mathrm{K}$ concentration, but they enable a low $\mathrm{K}$ intensity. However, soil 4 which had a low $\mathrm{PBC}^{\mathrm{K}}$ value would not maintain a given supply of potassium (Yawson et al., 2011). The low values of $\mathrm{PBC}^{\mathrm{K}}$ are caused by the few sites of soluble $\mathrm{K}$ it is shown in $\mathrm{Q} / \mathrm{I}$ isotherms of low buffering capacity. Moreover, the low $\mathrm{PBC}^{\mathrm{K}}$ values in the soil samples mean that the potassium fertilization should be added frequently for optimum crop yield (Sparks and Liebhardt, 1981 and Ldigbor et al., 2009). The high Kbuffering capacity also implies the high ability of the soil to maintain $\mathrm{K}$ and resist to potassium level change (Al-Zubaidi et al., 2008).

The Correlations Coefficients among QuantityIntensity Parameters and Some Soil Properties

The activity ratio $\left(\mathrm{AR}_{\mathrm{k}}{ }^{0}\right)$ has significantly negative correlation with organic matter, CEC, exchangeable potassium, and available $\mathrm{K}\left(\mathrm{r}=-0.633^{* *}, \mathrm{r}=-0.289^{*}, \mathrm{r}=-\right.$ $0.822^{* *}$, and $\mathrm{r}=-0.444^{*}$, respectively (Table 3 ). $\mathrm{AR}_{\mathrm{k}}{ }^{0}$ was positively and significantly correlated with $\mathrm{Ca}$ $\left(\mathrm{r}=0.709^{* *}\right)$ and $\mathrm{Mg}\left(\mathrm{r}=0.731^{* *}\right)$. However, $\mathrm{AR}_{\mathrm{k}}{ }^{0}$ correlations with $\mathrm{pH}$, clay, $\mathrm{EC}, \mathrm{CaCO}_{3}$, and $\mathrm{CEC}$ were not significant. Labile $\mathrm{K}\left(-\Delta \mathrm{K}^{0}\right)$ was positively correlated with clay, $\mathrm{Ca}_{\mathrm{ex}}, \mathrm{Mg}_{\mathrm{ex}},(\mathrm{r}=0.742 * *, \mathrm{r}=$ $\left.0.936^{* *}, \mathrm{r}=0.941^{* *}\right)$, respectively, but it was positively and non-significant with available $\mathrm{K}(\mathrm{r}=0.166)$. The $\Delta \mathrm{K}^{0}$ of the studied soil samples was significant and negatively correlated with $\mathrm{pH}, \mathrm{EC}, \mathrm{CaCO}_{3}$ and $\mathrm{K}_{\mathrm{ex}}$. On the other hand, the $-\Delta \mathrm{K}^{0}$ was positively correlated with clay content $\left(0.742^{* *}\right)$, OM $\left(0.567^{*}\right), \operatorname{CEC}\left(0.712^{* *}\right)$, $\mathrm{Ca}_{\mathrm{ex}}\left(0.936^{* *}\right)$ and $\mathrm{Mg}_{\mathrm{ex}}\left(0.941^{* *}\right)$. Also, the correlation coefficients between the potential buffering capacity $\left(\mathrm{PBC}^{\mathrm{K}}\right)$ and the clay content, silt, OM, CEC, Ca and $\mathrm{Mg}$ of the studied soils was positively significant and were $\mathrm{r}=0.844^{* *}, \mathrm{r}=0.410^{*}, \mathrm{r}=0.762^{* *}, \mathrm{r}=0.775^{* *}, \mathrm{r}=0.770^{* *}$ and $0.768^{* *}$, respectively. 

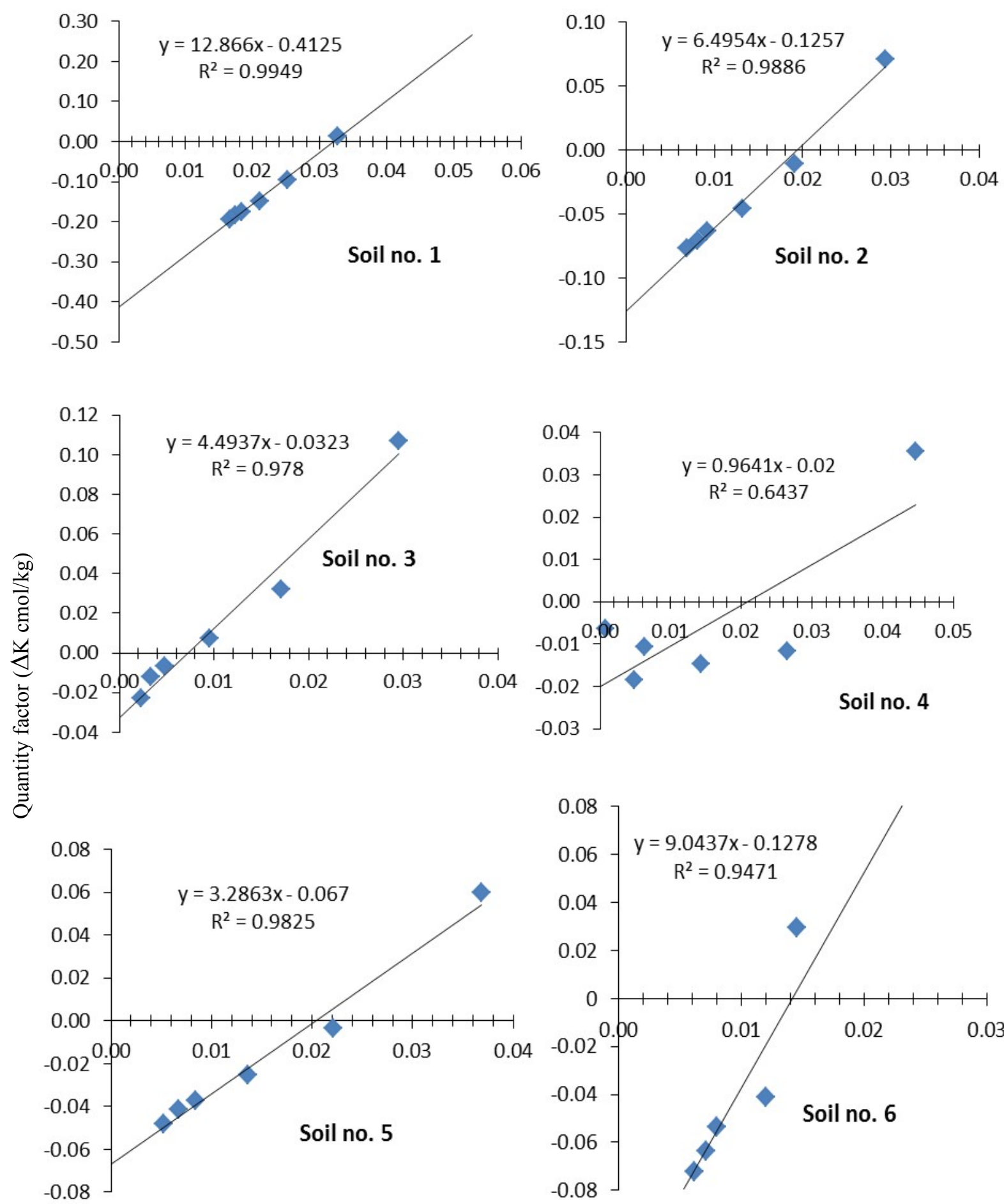

Intensity factor $\left(\mathrm{AR}^{\mathrm{K}}(\mathrm{mol} / \mathrm{l})^{0.5}\right)$

Figure 2. The $K$ quantity-intensity (Q/I) isotherms of the studied soil samples 
Table 3. The correlation coefficients between potassium quantity-intensity parameters and some soil properties

\begin{tabular}{lccc}
\hline Soil property & $\mathbf{A r}_{\mathbf{k}}{ }^{\mathbf{0}}$ & $-\Delta \mathbf{K}^{\mathbf{0}}$ & $\mathbf{P B C}^{\mathbf{K}}$ \\
\hline $\mathrm{Clay}(\%)$ & 0.179 & $0.742^{* *}$ & $0.844^{* *}$ \\
$\mathrm{Silt}(\%)$ & -0.371 & 0.161 & $0.410^{* *}$ \\
$\mathrm{pH}$ & 0.013 & -0.555 & $-0.795^{* *}$ \\
$\mathrm{EC} \mathrm{d} / \mathrm{Sm}$ & 0.254 & -0.187 & -0.396 \\
$\mathrm{CaCO}_{3}(\%)$ & 0.122 & $-0.407^{*}$ & $-0.633^{* *}$ \\
$\mathrm{OM}(\%)$ & $-0.633^{* *}$ & $0.567^{*}$ & $0.762^{* *}$ \\
$\mathrm{CEC}$ & $0.289^{*}$ & $0.712^{* *}$ & $0.775^{* *}$ \\
$\mathrm{Ca}$ & $0.709^{* *}$ & $0.936^{* *}$ & $0.770^{* *}$ \\
$\mathrm{Mg}_{\text {ex }}$ & $0.731^{* *}$ & $0.941^{* *}$ & $0.768^{* *}$ \\
$\mathrm{~K}_{\text {ex }}$ & $-0.822^{* *}$ & -0.334 & 0.027 \\
Available K & $-0.444^{*}$ & 0.166 & 0.381 \\
\hline
\end{tabular}

$* \mathrm{p}<0.05$ and ${ }^{* *} \mathrm{p}<0.01$

These results may be explained by the competitive relation existing between the activity of $\mathrm{K}$ and the activity ratio of $\mathrm{Ca}^{+2}$ and $\mathrm{Mg}^{+2}$ content (Abaslou and Abtahi, 2008). and Yeledhalli et al., 2011). Also,they reported that the $\mathrm{PBC}^{\mathrm{K}}$ had a significant positive correlation with the clay content $(\mathrm{r}=0.9944)$ indicating that the clay is responsible for the replenishment of soil solution $\mathrm{K}^{+}$. Also, the $\mathrm{PBC}^{\mathrm{K}}$ was significantly and negitively correlated with soil $\mathrm{pH}\left(\mathrm{r}=-0.795^{* *}\right)$ and $\mathrm{CaCO}_{3}\left(-0.633^{* *}\right)$. These relationships deserve more exploration to further understand potassium dynamics in soils and to ease modeling and prediction of $\mathrm{K}$ behavior in soils.

\section{CONCLUSION}

The studied soil samples showed variation in the physical-chemical properties, texture, $\mathrm{EC}, \mathrm{pH}$, organic carbon, $\mathrm{CaCO}_{3}$, and exchangeable $\mathrm{K}$. In this study, some soils had a high $\mathrm{K}$ intensity and lower in $\mathrm{PBC}^{\mathrm{K}}$. So, these soil samples will require frequent $\mathrm{K}$ fertilization. Generally, $\mathrm{AR}_{\mathrm{o}}{ }^{\mathrm{k}},-\Delta \mathrm{K}_{\mathrm{o}}$ and $\mathrm{PBC}^{\mathrm{k}}$ levels were increased with increasing the clay content and CEC of the studied soil samples. It is recommended that application of organic amendments to these soils, especially the sandy ones, can improve the potassium status, and $\mathrm{Q} / \mathrm{I}$ parameters of potassium.

\section{ACKNOWLEDGEMENT}

Special thanks go to the Assiut University, New Valey branch and my colleagues for their valuable help during the course of this study.

\section{REFERENCES}

Abaslou, H. and A.Abtahi, 2008. Potassium quantity-intensity parameters and its correlation with selected soil properties in some soils of Iran. Journal of Applied Sciences. 8(10): 1875-1882.

Al-Zubaidi, A., S. Yannil and, I. Bashour, 2008.Potassium status in some Lebanese soils. Lebanese Science Journal, Vol. 9, No. 1:81-97.
Awdenegest M, D. Melku, Y. Fantaw, 2013. Land use effects on soil quality indicators: A Case Study of Abo-Wonsho Southern Ethiopia. Appl. Environ. Soil Sci. P. 9.

Baruah, T.C. and H.P. Barthakur, 1997.A Textbook of soil analysis. Vikas Publishing House PVT LTD, New Delhi, India.

Brady, N.C. 1984. The Nature and Properties of Soils.Ninth Ed. Macmillan Publishing, New York, USA.

Diatta, J.B,Z. W. Kociałkowski and W. Grzebisz, 2006. Evaluation of potassium quantity/intensity parameters of selected polish agricultural soils.Electronic Journal of Polish Agricultural Universities. Agronomy, Volume 9, Issue 4.

Evangelou V.P., J.Wang and R.E. Phillips. 1994, New developments and perspectives on soil potassium quantity/intensity relationships. Adv. Agron. 52, 173-227.

Fanning, D.S., V.Z. Keramidas and M.A. El-Desoky, 1989. Micas. p. 551-634. In J. B. Dixon and S.B. Weed (eds.) Minerals in Soil. Environments.2nd edition. Soil Sci. Soc. Am., Madison, Wisconsin, USA.

Hamdan J., C.P.Burnham and, B.Ruhana, 1999. Evaluation of quantity-intensity of potassium in deeply weathered soil profile develops over granite from relationships Peninsular Malaysia. Commun. Soil Sci. Plant Anal. 30(17-18), 2311-2321.

Hesse, P.R, 1998. A Textbook of soil chemical analysis.CBS Publishers \& Distributors. Delhi, India.

Jackson, M. L., 1973. Soil chemical analysis.Prentice-Hall, Inc., Englewood Cliffs. N.J. New Delhi, pp. 88-97.

Jackson, M.L, 1969.Soil chemical analysis-advanced course.Published by the author, Soil Sci. Dept., Winsconsin Univ., Madison, USA.

Lalitha, M. and M. Dhakshinamoorthy, 2015. uantity-intensity characteristics of Potassium $(\mathrm{K})$ in relation to potassium availability under different cropping system in alluvial soils. Afri. J. of Agric. Res. Vol. 10(19), pp. 2097-2103.

Ldigbor C. M., D. O. Asawalam, E.U. Onweremaduand B.N. Ndukwu, 2009. Potassium Quantity-Intensity Relationship of Fauna Modified Soils of Abia State. International Journal of Sustainable Agriculture 1 (2): 49-52. 
LeRoux, J. and ME. Sumner, 1968. Labile potassium in soils. I. factors affecting the quantity-intensity $(\mathrm{Q} / \mathrm{I})$ parameters. Soil Sci. 106:25-41.

Nelson, R. E, 1982.Carbonate and gypsum.Cited by USDA (1991), Soil Survey Laboratory Methods Manual. Soil Survey Investigations Report No.42 Version 1: 280-284.

Olsen, S.R., C.V. Cole, F.S. Watanabe and L.A. Dean, 1954.Estimation of available phosphorus in soils by extraction with sodium bicarbonate. U.S. Dept. Agr.Circ. 939.

Raheb, A. and A.Heidari, 2012. Effects of clay mineralogy and physico-chemical properties on potassium availability under soil aquic conditions. J. Soil Sci. Plant Nutr. 12(4):747-776.

Roy, H.K., A. Kumar and A.K. Sarkar, 1991. Quantity/intensity relations of potassium in a representative acid sedentary. J.Indian Soc. Soil Sci. 39, 175-177.

Samadi, A., 2006. Potassium exchange isotherms as a plant availability index in selected calcareous soils of Western Azarbaijan province, Iran. Turk. J. Agric.30: 213-222.

Schneider, A. 1997.Influence of soil solution Ca concentration on short-term $\mathrm{K}$ release and fixation of a loamy soil.European J. Soil Sci. 48, 513-522.
Sparks, D.L. and W.C. Liebhardt, 1981.Effect of long-term lime and K application in sandy soil. Soil Sci. Soc. Am. J., 15: 786-90.

Sposito, G., 1989. The chemistry of soils. New York:Oxford University Press.

Usman, A. R. A. and M. A. Gameh. 2008. Effect of sugar industry wastes on $\mathrm{K}$ status and nutrient availability of a newly reclaimed loamy sandy soil. Arch. of Agron., and Soil Sci. Vol. 54: 665-675.

Wang, J.J., L.H. Dustin and F.B.Paul, 2004. Potassium bufferingcharacteristics of three soils low in exchangeable potassium.Soil Sci. Soc. Am. J. 68, 654-661.

Yawson, D. O., P. K. Kwakye, F. A. Armah, and K.A. Frimpong, 2011. Dynamics of potassium (k) in representative soil series of Ghana. ARPN Journal of Agricultural andBiological Science.VOL. 6, NO. 1, 111118.

Yeledhalli, N. A., S. S., Prakash, S. B., Gurumurthy, and M. V. Ravi, 2007. Coal Fly Ash as Modifier of PhysicoChemical and Biological Properties of Soil. Karnataka J. Agric. Sci. 20(3): 531-534.

Zharikova EA., 2004. Potential Buffer Capacity of Soils with Respect to Potassium (by the Example of the Amur River Region). Eurasian Soil Sci. 37(7):710-717.

\section{الملخص العربي}

\section{تقييم شدة وكمية البوتاسيوم فى بعض أراضى واحة الداخلة بالو ادى الجديا - مصر}

$$
\text { مهدى حسن حامد، أبو العيون أبو زيد أمين }
$$

و البوتاسيوم المتغير و السعة التتظيمية للبوتاسيوم فى عينات

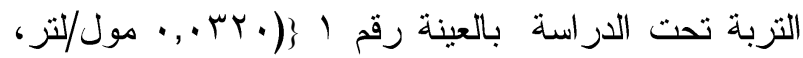

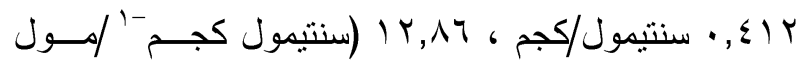

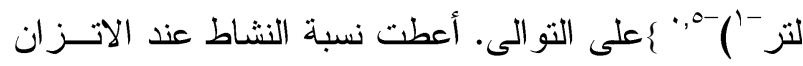

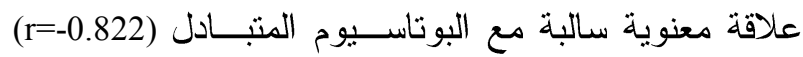

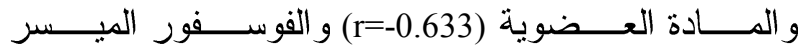
(r=-0.444). كذلك أعطى البوتاسيوم المتغير علاقة معنوية

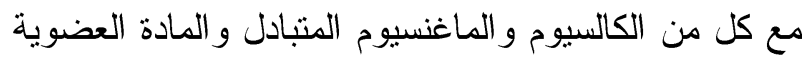

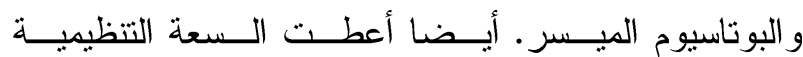

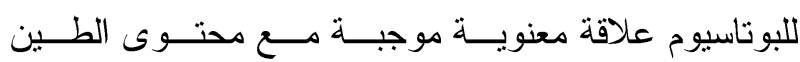
و البوتاسيوم الميسر و السعة التبادلية الكاتيونية، بينما أعطت

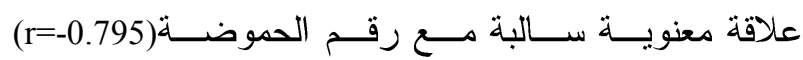
وكربونات الكالسييوم (r=-0.633).
أجريت هذه الدر اسة فى عام 17 . ب بهدف تقييم مقاييس

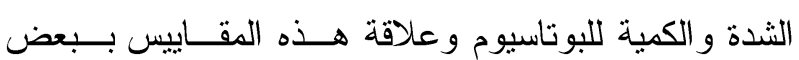

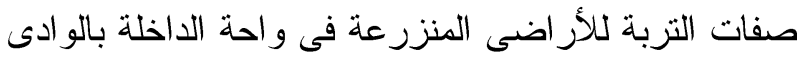
الجديد-مصر • حيث نم جمع ستة عينات نزبة من الطبقـــة

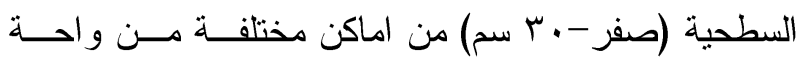

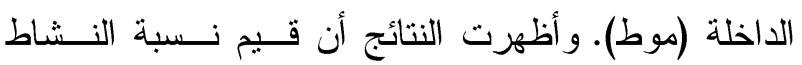

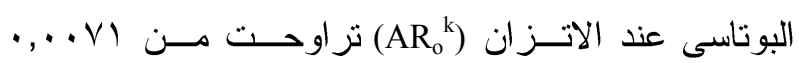

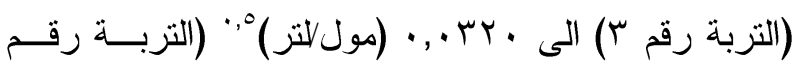

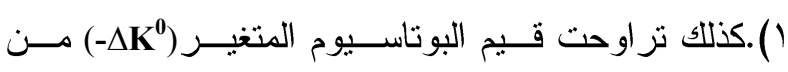

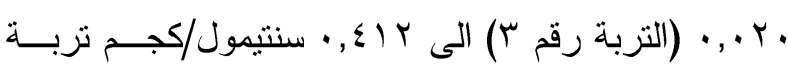

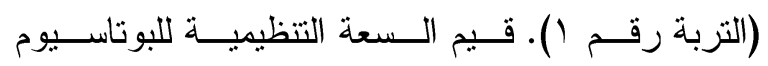
(PBC $\left.{ }^{k}\right)$

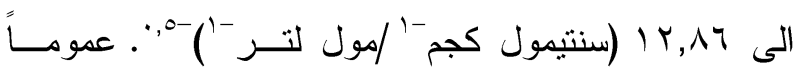

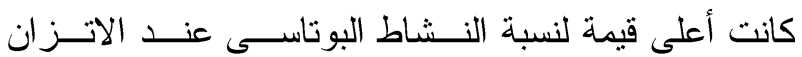

